\title{
Article \\ LED and HPS Supplementary Light Differentially Affect Gas Exchange in Tomato Leaves
}

\author{
Onofrio Davide Palmitessa ${ }^{1,2, * \mathbb{C}}$, Aina E. Prinzenberg ${ }^{2,3}$, Elias Kaiser $^{2} \mathbb{D}$ and Ep Heuvelink ${ }^{2}$ \\ 1 Department of Agricultural and Environmental Science, University of Bari Aldo Moro, 70126 Bari, Italy \\ 2 Horticulture and Product Physiology, Wageningen University and Research, PO Box 16, \\ 6700 AA Wageningen, The Netherlands; aina.prinzenberg@gmx.de (A.E.P.); elias.kaiser@wur.nl (E.K.); \\ ep.heuvelink@wur.nl (E.H.) \\ 3 Plant Breeding Laboratory, Wageningen University and Research, PO Box 386, \\ 6700 AJ Wageningen, The Netherlands \\ * Correspondence: onofrio.palmitessa@uniba.it
}

Citation: Palmitessa, O.D.; Prinzenberg, A.E.; Kaiser, E.; Heuvelink, E. LED and HPS Supplementary Light Differentially Affect Gas Exchange in Tomato Leaves. Plants 2021, 10, 810. https:// doi.org/10.3390/plants10040810

Academic Editor: Agnieszka Klimek-Kopyra

Received: 13 March 2021

Accepted: 16 April 2021

Published: 20 April 2021

Publisher's Note: MDPI stays neutral with regard to jurisdictional claims in published maps and institutional affiliations.

Copyright: (c) 2021 by the authors. Licensee MDPI, Basel, Switzerland. This article is an open access article distributed under the terms and conditions of the Creative Commons Attribution (CC BY) license (https:/ / creativecommons.org/licenses/by/ $4.0 /)$.
Abstract: Using light emitting diodes (LED) instead of conventionally used high pressure sodium (HPS) lamps as a supplemental light source in greenhouses results in a higher efficacy ( $\mu \mathrm{mol}$ light per J electricity) and makes it possible to customize the light spectrum. To explore the effects of LED and HPS on gas exchange, thermal relations, photosynthesis, and water status of young tomato plants, seven genotypes were grown in a greenhouse under LED (95\% red, 5\% blue) or HPS lamps in four experiments differing in the fraction of lamp light over natural light. HPS lights emit a broader spectrum of red (40\%), green-yellow (50\%), blue (5\%), and far-red (5\%) and a substantial amount of infrared radiation (heat). Young tomato plants grown under LED showed lower leaf temperature and higher stomatal density, stomatal conductance $\left(g_{s}\right)$ and transpiration rate $(E)$ than plants grown under HPS; this may be due to the different supplemental light spectrum. The young plants grown under LED tended to have increased photosynthetic capacity. Furthermore, the water stress indices CWSI and $I_{G}$, which were obtained using thermal imaging, were positively correlated with gas exchange-derived $g_{s}$ and $E$, putting forward the use of thermal imaging for the phenotyping of transpiration. Under LED light, photosynthetic gas exchange was generally increased, which agreed with the water stress indices. The extent of this increase was genotype-dependent. All differences between LED and HPS were smaller in the experiments where the fraction of lamp light over natural light was smaller.

Keywords: greenhouse; photosynthesis; stomatal conductance; thermal imaging; transpiration rate; leaf temperature

\section{Introduction}

In the northern hemisphere, tomato nurseries must meet the peak demand for transplants during a period when the daily light integral (DLI; mol photons $\mathrm{m}^{-2} \mathrm{~s}^{-1}$ ) of natural light is lowest [1]. Supplementary light (SL) is frequently applied to improve tomato seedling quality [2-5], and high-pressure sodium lamps (HPS; [6]) are commonly used as a supplementary light source in greenhouses. HPS emit photosynthetically active radiation (PAR), but also infrared radiation [7], heating up the leaves. More recently, light emitting diodes (LED) have been investigated as a possible alternative for HPS in greenhouses. Their efficacy ( $\mu \mathrm{mol}$ per J) is higher compared to HPS lamps [8], with less radiant heat output and a longer lifetime compared to HPS. LED and HPS lamps dissipate thermal energy differently. While LED fixtures dissipate a large part of heat through natural or forced convection, HPS lamps have a high operating temperature and emit longwave radiation (3000-100,000 $\mathrm{nm}$ ) in the same direction as photosynthetically active radiation, i.e., towards the plants [9]. LED also allows one to customize the light spectrum. However, to optimize light use efficiency, plants must adapt their physiology and morphology to 
a given light spectrum in a process called light acclimation [10]. Acclimation may also include changes in photosynthetic capacity, which can be brought about by changes in the concentration of, e.g., Rubisco [11]. Acclimation of a plant to a light environment is characterized by changes in its phenotype (environmental plasticity) and is influenced by the plant's genetics [12]. For instance, Liu et al. [13] and Wang et al. [14] found that during long-term acclimation to specific light spectra, stomatal morphology, density and opening rates were changed, with effects on overall gas exchange. Apart from the light spectrum, plants will likely need to adapt differentially to the reduced heat radiation when grown under LED compared to HPS light. For example, Nelson and Bugbee [9] found that LED modules reduced leaf temperature compared to HPS lamps. Giuliani et al. [15] found that leaf temperature affects leaf anatomy during development, biochemistry (including photosynthetic capacity), transpiration and stomatal conductance. Stomatal conductance is an important physiological trait, as stomatal behavior impacts photosynthetic $\mathrm{CO}_{2}$ uptake, transpiration, and temperature, all of which influence plant growth and water status [16]. The light spectrum influences the regulation of stomatal movements, and the combination of red (R) and blue (B) light stimulates stomatal opening [17,18]. Eisinger et al. [19] found that sole green $(G)$ light also induced stomatal opening. However, $G$ light reversed the $B$ light-stimulated opening of stomata when it was given simultaneously with continuous B-light $[20,21]$. It is argued that the B:G light ratio is a signal for the plants to regulate stomatal conductance, in order to balance photosynthesis and water use efficiency [22]. Leaf gas exchange is further affected by the genotype [23]. Therefore, the impact of the supplemental light spectrum on transpiration can be expected to be genotype-dependent. Diversity between varieties provides the opportunity to discover genotypes with desirable traits (e.g., high-water use efficiency) that, when crossed with high-yielding varieties, could produce progenies with improved performance and yield under a given environment. However, identifying individuals with the desired eco-physiological and agronomic responses and traits requires the development of appropriate phenotyping tools [24]. In this regard, thermography can be used to derive estimates of stomatal conductance under a dynamic environment, thereby opening up a new avenue for plant phenotyping and selection [25]. From thermographic images, different parameters can be obtained: the thermal index $\left(\mathrm{I}_{\mathrm{G}}\right)$, which describes thermal differences and the crop water stress index (CWSI), which is an index for water stress-both are positively correlated with stomatal conductance $[26,27]$.

LED can improve the biomass production of young tomato plants due to the higher photosynthetic efficiency of the plants, compared to HPS lamps [5], but the underlying physiological process(es) are not well understood. During this study, we hypothesize that leaves of young tomato plants grown under HPS have higher temperature and therefore higher evaporative demand than leaves grown under LED. Therefore, leaves grown under HPS might have higher stomatal conductance, transpiration rate and stomatal density; furthermore, we hypothesize that the extent of acclimation to a given light source is genotype-dependent. At the same time, G radiation in HPS lamps may reverse B light-induced stomatal opening, thus possibly reducing gas exchange and photosynthetic efficiency. The aim of this study was to determine how two different supplemental lights, HPS and LED, influence gas exchange parameters of different young tomato plants, with a focus on leaf temperature. Thermography was assessed as a technique to determine differences between genotypes in stomatal conductance and transpiration rate from CWSI and $\mathrm{I}_{\mathrm{G}}$.

\section{Results}

\subsection{Stomatal Conductance $\left(g_{s}\right)$ and Transpiration Rate (E)}

Based on porometer measurements, plants grown under LED showed a significantly higher $g_{s}(p<0.05$ or $p<0.001$, depending on the experiment) than plants grown under HPS lamps; on average, $g_{s}$ was $6 \%$ higher under LED (Table 1). Across experiments, 'Rutgers' showed the lowest $g_{s}$ and 'LA1578' showed the highest $g_{s}$ values. Additionally, 
there was a significant genotype by light treatment interaction (Table 1) that varied per experiment (Table 1, Figure 1). The ratio of $g_{s}$ under LED divided by $g_{s}$ under HPS across experiments showed no significant differences between genotypes (Table S1). However, while most genotypes showed an on average between 4 and $20 \%$ higher $g_{s}$ under LED light, the genotype 'LA1578' had a 5\% lower $g_{s}$ under LED than under HPS light (Figure 1). Thus, lamp type effects on $g_{s}$ were genotype-specific.

Table 1. Stomatal conductance (measured using a porometer) in seven tomato genotypes grown under HPS and LED supplemental light, in four experiments differing in fraction of SL over natural light (treatments: $n=21$; genotypes: $n=3$ ). Significance was tested by two-way ANOVA. Means followed by different letters within a column indicate significant differences according to Fisher's protected LSD test $(p=0.05)$. SL-supplemental light treatments; Gn-genotypes; SL $\times$ Gn-interaction between SL and $G_{n}$.

\begin{tabular}{|c|c|c|c|c|}
\hline \multirow[b]{2}{*}{ Experiment } & \multicolumn{4}{|c|}{ Stomatal Conductance $\left(\mathrm{mol} \mathrm{H}_{2} \mathrm{O} \mathrm{m}^{-2} \mathrm{~s}^{-1}\right)$} \\
\hline & 1 & 2 & 3 & 4 \\
\hline \multicolumn{5}{|l|}{ Treatments (SL) } \\
\hline HPS & $0.32 \mathrm{~b}$ & $0.37 \mathrm{~b}$ & $0.59 \mathrm{~b}$ & $0.56 \mathrm{~b}$ \\
\hline LED & $0.35 \mathrm{a}$ & $0.40 \mathrm{a}$ & $0.66 \mathrm{a}$ & $0.60 \mathrm{a}$ \\
\hline \multicolumn{5}{|l|}{ Genotypes $\left(G_{n}\right)$} \\
\hline Moneymaker & $0.36 \mathrm{a}$ & $0.39 \mathrm{ab}$ & $0.62 \mathrm{~b}$ & $0.56 \mathrm{~cd}$ \\
\hline Momotaro & $0.36 \mathrm{a}$ & $0.41 \mathrm{a}$ & $0.61 \mathrm{~b}$ & $0.54 \mathrm{~d}$ \\
\hline LA1578 & - & $0.36 \mathrm{~b}$ & $0.73 \mathrm{a}$ & $0.66 \mathrm{a}$ \\
\hline Rutgers & $0.31 \mathrm{~b}$ & $0.36 \mathrm{~b}$ & $0.56 \mathrm{c}$ & $0.50 \mathrm{e}$ \\
\hline Kentucky Beefsteak & $0.29 \mathrm{~b}$ & $0.38 \mathrm{ab}$ & $0.63 \mathrm{~b}$ & $0.62 \mathrm{~b}$ \\
\hline Nunhems-FM001 & $0.35 \mathrm{a}$ & $0.41 \mathrm{a}$ & $0.60 \mathrm{bc}$ & $0.62 \mathrm{~b}$ \\
\hline Ailsa Craig & $0.32 \mathrm{~b}$ & $0.40 \mathrm{a}$ & $0.61 \mathrm{~b}$ & $0.58 \mathrm{c}$ \\
\hline \multicolumn{5}{|l|}{ Significance $^{1}$} \\
\hline SL & * & * & $* *$ & $* * *$ \\
\hline $\mathrm{G}_{\mathrm{n}}$ & $* * *$ & * & $* * *$ & $* * *$ \\
\hline $\mathrm{SL} \times \mathrm{G}_{\mathrm{n}}$ & * & $* * *$ & NS & $* *$ \\
\hline
\end{tabular}

${ }^{1}$ Significance: ${ }^{* * *},{ }^{* *}$, and ${ }^{*}$ for $p \leq 0.001, p \leq 0.01$, and $p \leq 0.05$, respectively; NS—not significant.

The highest values for transpiration $(E)$, measured using the LI-6400, were again found in plants grown under LED (2-24\% higher than HPS depending on experiment; Table S1). Similarly, as for $g_{s}$, 'Rutgers' showed low values for $E$ across treatments in all experiments, but these were not significantly different from those of other genotypes (Table S2).

\subsection{Stomatal Density}

Leaves grown under LED showed an on average $\sim 14 \%$ higher stomatal density compared to HPS (Table 2), concomitant with an increase in $g_{s}$ under LED. The difference in stomatal number per unit area in LED compared to HPS varied between genotypes, with significant differences of ca. $11 \%, 18 \%$ and $37 \%$ for the genotypes 'Moneymaker', 'Nunhems' and 'Rutgers', respectively (Table 2). Across experiments 3 and 4, the lowest stomatal density was found among the genotypes 'Rutgers' and 'Ailsa Craig' (Table 2). The genotype with the highest stomatal density was 'LA1578', again matching with the highest $g_{s}$ for this genotype (Table 1). The difference in stomatal density between 'Rutgers' (Figure S1) and the genotype 'LA1578' was significant under both light conditions. 'LA1578' had $49 \%$ and 57\% more stomata than 'Rutgers' under HPS and LED light, respectively (Table 2).

\subsection{Leaf Temperature}

Leaf temperature tended to be higher under HPS compared to LED lamps, although large differences between single experiments were apparent (Table 3). Variation between experiments was most likely caused by differences in sunlight intensity (Figure S2). In the first two experiments, a significantly higher leaf temperature was measured under HPS: this difference was $1.8^{\circ} \mathrm{C}$ in experiment $1(p<0.001)$, and $0.8^{\circ} \mathrm{C}$ in experiment 2 $(p<0.001)$. No leaf temperature differences were found in the two consecutive experiments (Table 3), where sunlight represented a larger part of total PPFD (Figure S2). No differences in average leaf temperature were found between genotypes. 


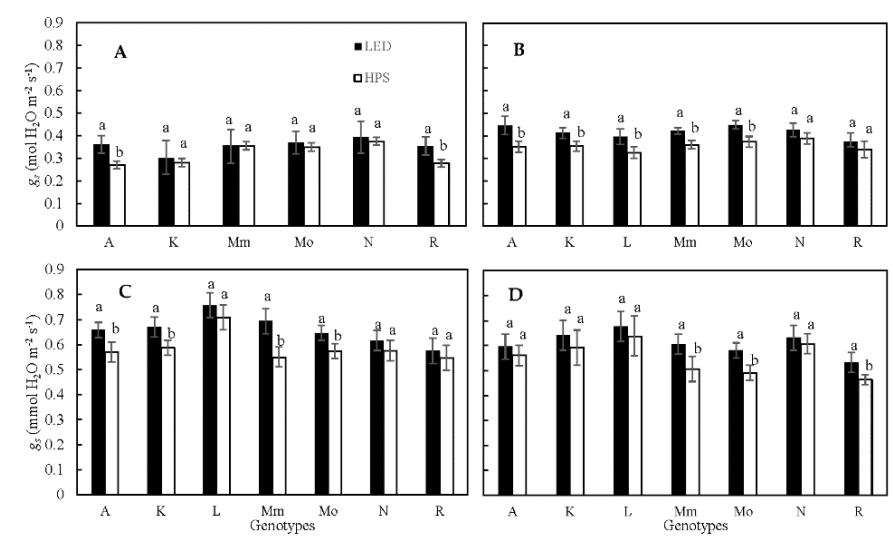

Figure 1. Stomatal conductance $\left(g_{s}\right)$ per genotype grown under HPS and LED supplemental light (measured using porometer), during Expt. 1-4 (A-D). Values are the average of measurements from 3 plants per genotype. Different letters above bars within a panel and for each genotype separately indicate significant differences according to Fisher's protected LSD test $(p=0.05)$. Error bars show \pm SD. A-Ailsa Craig; K-Kentucky Beefsteak; L-LA1578; Mm-Moneymaker; MoMomotaro; N-Nunhems-FM00; R-Rutgers.

Table 2. Stomatal density $\pm \mathrm{SE}\left(\mathrm{mm}^{-2}\right)$ in seven tomato genotypes grown under HPS and LED supplemental light, in two experiments differing in fraction of SL over natural light (treatments: $n=21$; genotypes: $n=3$ ). Significance was tested by two-way ANOVA. Means followed by different letters within a column indicate significant differences according to Fisher's protected LSD test $(p=0.05)$. SL-supplemental light treatments; $\mathrm{G}_{\mathrm{n}}$ - genotypes; $\mathrm{SL}-\mathrm{G}_{\mathrm{n}}$-interaction between SL and $\mathrm{Gn}$.

\begin{tabular}{|c|c|c|}
\hline \multirow[b]{2}{*}{ Experiment } & \multicolumn{2}{|c|}{ Stomatal Density (Number $\mathrm{mm}^{-2}$ ) } \\
\hline & 1 & 4 \\
\hline \multicolumn{3}{|l|}{ Treatment (SL) } \\
\hline HPS & $185 \pm 9 b$ & $186 \pm 7 b$ \\
\hline LED & $216 \pm 11 \mathrm{a}$ & $205 \pm 8 \mathrm{a}$ \\
\hline \multicolumn{3}{|l|}{ Genotype $\left(G_{n}\right)$} \\
\hline Moneymaker & $192 \pm 13 \mathrm{bcd}$ & $176 \pm 6 c$ \\
\hline Momotaro & $195 \pm 13 \mathrm{bc}$ & $188 \pm 13 \mathrm{bc}$ \\
\hline LA1578 & $276 \pm 14 \mathrm{a}$ & $347 \pm 7 a$ \\
\hline Rutgers & $168 \pm 8 \mathrm{~cd}$ & $135 \pm 8 \mathrm{~d}$ \\
\hline Kentucky Beefsteak & $214 \pm 11 b c$ & $193 \pm 7 \mathrm{bc}$ \\
\hline Nunhems-FM001 & $216 \pm 11 b$ & $210 \pm 10 \mathrm{~b}$ \\
\hline Ailsa Craig & $95 \pm 11 \mathrm{~d}$ & $136 \pm 7 \mathrm{~d}$ \\
\hline \multicolumn{3}{|l|}{ Significance ${ }^{1}$} \\
\hline$S L$ & $* * *$ & $* *$ \\
\hline $\mathrm{G}_{\mathrm{n}}$ & $* * *$ & $* * *$ \\
\hline $\mathrm{SL} \times \mathrm{G}_{\mathrm{n}}$ & NS & NS \\
\hline
\end{tabular}

\subsection{Plant Water Stress Indices}

Thermography was used as a technique to detect possible differences in physiologically desirable traits between the genotypes and to estimate $g_{s}$ and $E$ from CWSI and $\mathrm{I}_{\mathrm{G}}$. In the first three experiments, CWSI was significantly $(p<0.01)$ lower, by $5-18 \%$, in plants grown under HPS than under LED light (Table 4); during experiment 2, the largest treatment effect was seen for LA1578, with a $24 \%$ reduced CWSI in HPS compared to LED. The smallest impact of light treatments was found in 'Rutgers', with a decrease of only $2 \%$ (Figure 2). Like the CWSI, $\mathrm{I}_{\mathrm{G}}$ was increased by between 14 and 32\% under LED compared to HPS during the first three experiments, while in the fourth experiment no difference could be identified (Table S3).

\section{5. $\mathrm{CO}_{2}$ Response of Net Photosynthesis Rate}

To assess the effects of SL type on photosynthetic capacity, the response of net photosynthesis rate to internal $\mathrm{CO}_{2}$ partial pressure was measured in experiments 1,3 and 4 , and the parameters $\mathrm{V}_{\mathrm{c}, \max }, \mathrm{J}_{1500}$ and TPU were extracted by curve fitting (Figure 3). 
In experiments 1 and 3, all three parameters were significantly higher in leaves grown under LED compared to those under HPS (Figure 3); there were no differences between light treatments in experiment $4 . \mathrm{V}_{\mathrm{c} \text {,max }}$ was the parameter that differed most strongly between genotypes, with 'Rutgers' and 'Kentucky Beefsteak' showing significantly lower values during experiments 1 and 3 (Figure 3J,K). $\mathrm{J}_{1500}$ and TPU were less variable between genotypes, as both were only significantly reduced compared to the other genotypes in 'Rutgers' and 'Kentucky Beefsteak' in experiment 3 (Figure 3E,F).

Table 3. Leaf temperature $\pm \mathrm{SE}\left({ }^{\circ} \mathrm{C}\right)$ in seven tomato genotypes grown under HPS and LED supplemental light, in four experiments differing in fraction of SL over natural light (treatments: $n=21$; genotypes: $n=3$ ). Significance was tested by two-way ANOVA. Means followed by different letters within a column indicate significant differences according to Fisher's protected LSD test $(p=0.05)$. SL—supplemental light treatments.

\begin{tabular}{|c|c|c|c|c|}
\hline \multirow[b]{2}{*}{ Experiment } & \multicolumn{4}{|c|}{ Leaf Temperature $\left({ }^{\circ} \mathrm{C}\right)$} \\
\hline & 1 & 2 & 3 & 4 \\
\hline \multicolumn{5}{|l|}{ Treatment (SL) } \\
\hline HPS & $23.8 \pm 1.4 \mathrm{a}$ & $21.9 \pm 1.0 \mathrm{a}$ & $22.0 \pm 1.5 \mathrm{a}$ & $23.4 \pm 0.9 a$ \\
\hline LED & $22.0 \pm 1.2 \mathrm{~b}$ & $21.1 \pm 0.7 \mathrm{~b}$ & $22.4 \pm 1.0 \mathrm{a}$ & $23.1 \pm 1.2 \mathrm{a}$ \\
\hline \multicolumn{5}{|l|}{ Significance $^{1}$} \\
\hline SL & $* * *$ & $* * *$ & NS & NS \\
\hline
\end{tabular}

${ }^{1}$ Significance: ${ }^{* * *}$ for $p \leq 0.001$; NS-not significant.

Table 4. Crop water stress index (CWSI) in seven tomato genotypes grown under HPS and LED supplemental light, in four experiments differing in fraction of SL over natural light (treatments: $n=21$; genotypes: $n=3$ ). Significance was tested by two-way ANOVA. Means followed by different letters within a column indicate significant differences according to Fisher's protected LSD test $(p=0.05)$. SL—supplemental light treatments; $\mathrm{G}_{n}$-genotypes; $\mathrm{SL} \times \mathrm{G}_{\mathrm{n}}$-interaction between SL and $\mathrm{Gn}$.

\begin{tabular}{|c|c|c|c|c|}
\hline \multirow[b]{2}{*}{ Experiment } & \multicolumn{4}{|c|}{ Crop Water Stress Index (CWSI) } \\
\hline & 1 & 2 & 3 & 4 \\
\hline \multicolumn{5}{|l|}{ Treatments (SL) } \\
\hline HPS & $0.53 \mathrm{~b}$ & $0.54 \mathrm{~b}$ & $0.65 \mathrm{~b}$ & $0.68 \mathrm{a}$ \\
\hline LED & $0.58 \mathrm{a}$ & $0.66 \mathrm{a}$ & $0.69 \mathrm{a}$ & $0.69 \mathrm{a}$ \\
\hline \multicolumn{5}{|l|}{ Genotypes $\left(G_{n}\right)$} \\
\hline Moneymaker & $0.63 \mathrm{a}$ & $0.70 \mathrm{a}$ & 0.63 de & $0.70 \mathrm{~b}$ \\
\hline Momotaro & $0.56 \mathrm{~b}$ & $0.63 \mathrm{~b}$ & $0.70 \mathrm{~b}$ & $0.64 \mathrm{de}$ \\
\hline LA1578 & - & $0.62 \mathrm{~b}$ & $0.69 \mathrm{bc}$ & $0.76 \mathrm{a}$ \\
\hline Rutgers & $0.58 \mathrm{ab}$ & $0.61 \mathrm{~b}$ & $0.59 \mathrm{e}$ & $0.61 \mathrm{e}$ \\
\hline Kentucky Beefsteak & $0.46 \mathrm{c}$ & $0.59 \mathrm{~b}$ & $0.67 \mathrm{bcd}$ & $0.67 \mathrm{bc}$ \\
\hline Nunhems-FM001 & $0.50 \mathrm{c}$ & $0.58 \mathrm{~b}$ & $0.65 \mathrm{~cd}$ & $0.66 \mathrm{~cd}$ \\
\hline Ailsa Craig & $0.59 \mathrm{ab}$ & $0.48 \mathrm{c}$ & $0.75 \mathrm{a}$ & $0.75 \mathrm{a}$ \\
\hline \multicolumn{5}{|l|}{ Significance $^{1}$} \\
\hline$S L$ & ** & $* * *$ & $* *$ & NS \\
\hline $\mathrm{G}_{\mathrm{n}}$ & $* * *$ & $* * *$ & $* * *$ & $* * *$ \\
\hline $\mathrm{SL} \times \mathrm{G}_{\mathrm{n}}$ & NS & $* * *$ & $* * *$ & NS \\
\hline
\end{tabular}

\subsection{Correlations between Physiological Parameters}

Using individual data across SL conditions and genotypes, a positive correlation was found between $g_{s}$ and stomatal density $(\mathrm{r}=0.67$; Figure 4$)$ and between $E$ and stomatal density $(\mathrm{r}=0.67$; Figure 4$) . g_{s}$ and $E$ were positively correlated with CWSI and $\mathrm{I}_{\mathrm{G}}(\mathrm{r}=0.58-0.72$; Figure 4). Leaf temperature and $E$ are the variables used to calculate $g_{s}$ in the LI-6400, hence (strong) correlations between these variables are to be expected. Between $g_{s}$ and E, the correlation coefficient was 0.99, while between CWSI and Ig, this was 0.98 (Figure 4). Significant $(p<0.05)$ negative correlations were found between leaf temperature and $g_{s}$ and $\mathrm{E}(\mathrm{r}=-0.39$; Figure 4$)$, in agreement with the cooling capacity of leaf transpiration. Significant positive correlations were found among parameters related to photosynthetic capacity $\left(\mathrm{V}_{\mathrm{c}, \max }, \mathrm{J}_{1500}\right.$ and TPU), while no correlations were found between these and other physiological parameters (Figure 4). 


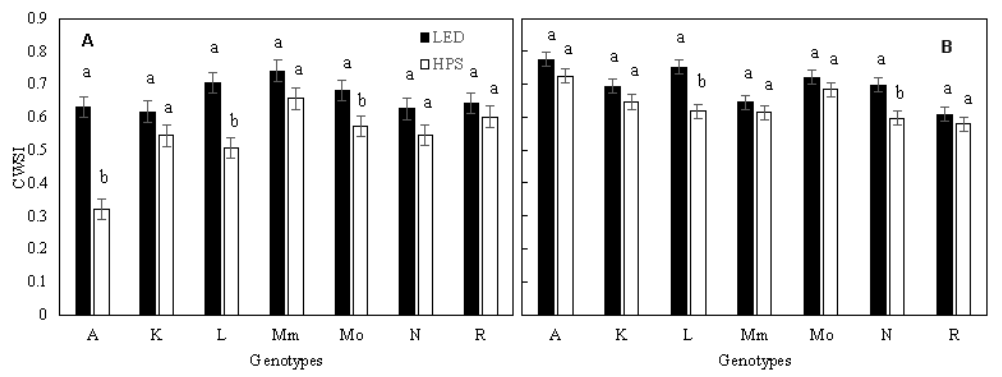

Figure 2. Crop water stress index (CWSI) per genotype, grown under HPS and LED supplemental light. Values are the average of 3 plants per genotype in experiment 2 (A) and experiment 3 (B). Different letters above bars within a panel and for each genotype separately indicate significant differences according to Fisher's protected LSD test $(p=0.05)$. Error bars show \pm SD. A-Ailsa Craig; K-Kentucky Beefsteak; L-LA1578; Mm-Moneymaker; Mo-Momotaro; N-Nunhems-FM001; R-Rutgers.

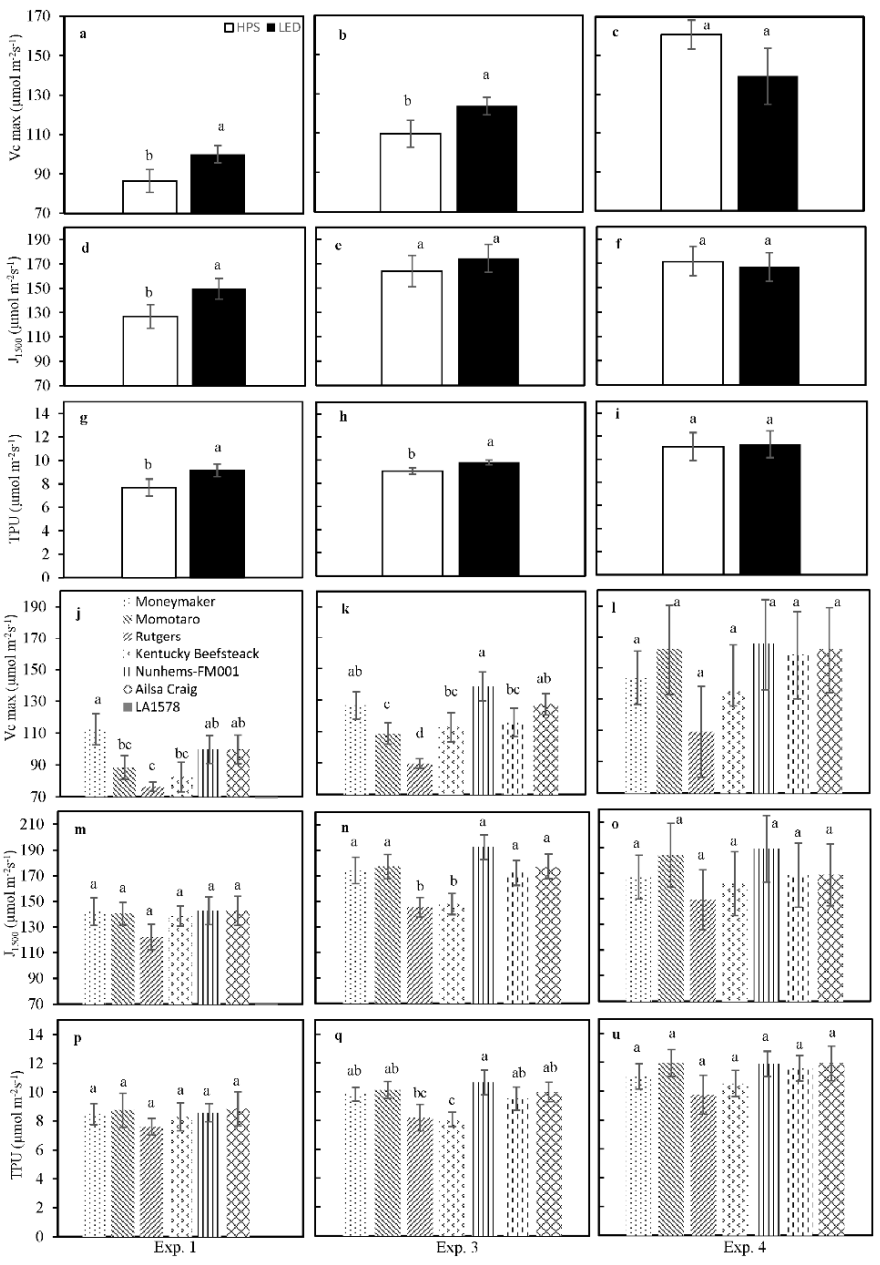

Figure 3. Photosynthetic capacity as affected by supplemental lighting type (HPS or LED) and genotype. $\mathrm{V}_{\mathrm{c}, \max }, \mathrm{J}_{1500}$ and TPU compared in experiment (Exp.) $1(\mathbf{a}, \mathbf{d}, \mathbf{g}, \mathbf{j}, \mathbf{m}, \mathbf{p})$, Exp. 3 (b,e,h, $\left.\mathbf{k}, \mathbf{n}, \mathbf{q}\right)$ and Exp. $4(\mathbf{c}, \mathbf{f}, \mathbf{i}, \mathbf{l}, \mathbf{o}, \mathbf{u})$ between the supplemental light conditions (from a to $\mathbf{i}$ ) and between genotypes (from $\mathbf{j}$ to $\mathbf{u}$ ). Different letters on top of a bar within each panel indicate significant differences according to Fisher's protected LSD test $(p=0.05)$. Error bars show \pm SE (supplementary light: $n=21$; genotypes: $n=3$ ). 


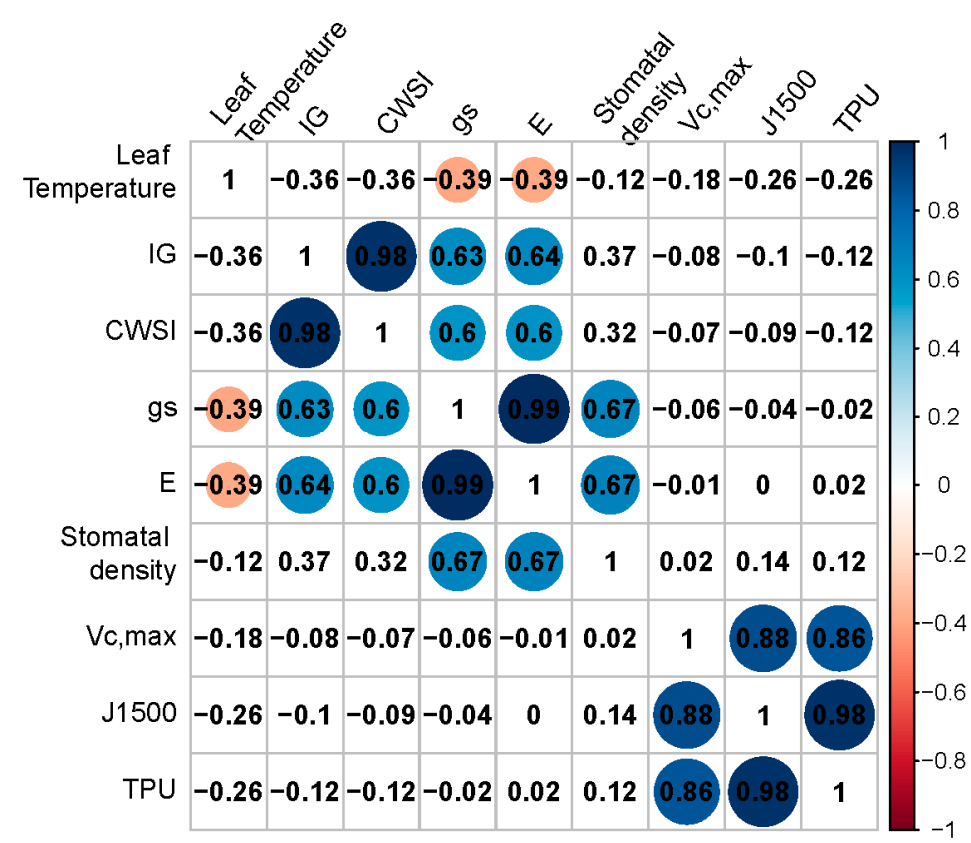

Figure 4. Correlation matrix between leaf temperature, thermal index $\left(\mathrm{I}_{\mathrm{G}}\right)$, crop water stress index (CWSI), stomatal conductance $\left(g_{s}\right)$, transpiration rate $(E)$, stomatal density, maximum carboxylation rate $\left(\mathrm{V}_{\mathrm{cmax}}\right)$, electron transport rate at $1500 \mu \mathrm{mol} \mathrm{m} \mathrm{m}^{-2} \mathrm{~s}^{-1}\left(\mathrm{~J}_{1500}\right)$ and maximum triose phosphate utilization rate (TPU), across all experiments (4 experiments $\times 7$ genotypes, hence $n=28$ ). Numbers represent Pearson's correlation coefficient; blue circles represent positive correlations $(p<0.05)$ and red circles represent negative correlations $(p<0.05)$. Size of circle depends on height of correlation, while in the cells without circle, no statistically significant correlations were found. Pearson's correlation test was performed.

\section{Discussion}

Seven tomato genotypes were grown under HPS or LED supplementary light in four experiments, differing in the ratio between SL and natural light. The aim of this study was to determine how HPS and LED influence gas exchange parameters of different tomato genotypes, with a focus on leaf temperature. The experiments show reproducible differences between the compartments with the different SL.

\subsection{High Pressure Sodium (HPS) and LED Supplemental Light Influenced Leaf Temperature}

The plants under HPS light are more strongly exposed to heat radiation from the lamps and Nelson and Bugbee [9] reported that about 95\% of all longwave radiation is absorbed by leaves, increasing leaf temperature. According to Nelson and Bugbee [9], we observed higher leaf and meristem temperatures under HPS than under LED (Table 3). This was likely due to a larger fraction of longwave and IR radiation from HPS than LED (Table 5) and a lower rate of transpiration (Table 1 and Table S2). Differences in leaf temperature between HPS and LED were smaller when the fraction of SL in total light decreased (Experiment 4; Figure S2). Since transpiration was not higher in experiment 4, similar leaf temperatures for HPS and LED may be due to the IR provided by the sun that warmed up the leaves of plants under LED. This would support the idea that the plants did not adapt their rate of transpiration with increasing IR and leaf temperature was primarily controlled by irradiation. Transpiration capacity decreased under HPS because of lower $g_{s}$ compared to LED. On the interaction between leaf temperature and stomatal behavior, the literature is often contradictory: Mott and Peak [28] found that with increasing leaf temperature, $g_{s}$ increased; Von Caemmerer and Evans [29] observed that some species showed large increases in $g_{s}$ with increasing leaf temperature; Lahr et al. [30] found that increasing leaf temperature stimulated stomatal closure; Bañon et al. [31] observed a negative correlation between leaf temperature and stomatal density; and Farquhar and 
Sharkey [32] observed negative correlations between $g_{s}$ and leaf temperature. These contradictory results are probably due to several other factors that can affect both leaf temperature and stomatal behaviour (environmental conditions, genotypes, cultivation technique, etc.). While leaf temperature was negatively correlated with $g_{s}$ and $E$, stomatal density was positively correlated $(p \leq 0.001)$ with both (Figure 4$)$, according to the findings of Zhenzhu and Guangsheng [33]. Stomatal conductance is a measure of the degree of stomatal opening and density and is a physiological variable related to the regulation of water and carbon assimilation. Moreover, $g_{s}$ can be used as an indicator of plant water status [34]. Transpiration rate $(E)$ is closely related to water movement through a plant and its transpiration from leaves, stems, and flowers. $E$ is integral to the calculation of $g_{s}$, as is leaf temperature. Leaves from plants grown under HPS showed lower $g_{s}$ and $E$ than from plants grown under LEDs (Figure 1). Therefore, since the large genotypic effects found for $g_{s}, E$ and stomatal density were not found back in the leaf temperature difference of the genotypes, there seem to be other physiological factors, such as stomata opening or leaf architecture, linked to leaf temperature regulation. In fact, if leaf temperature did not differ much between genotypes, 'Ailsa Craig' and 'Rutgers' showed the lowest $g_{s}$ and stomatal density and 'LA1578', on average, showed the highest $g_{s}$ and stomatal density (Tables 1 and 2). This confirms the hypothesis that tomato plant gas exchange varied, responding to the supplemental light spectrum and that acclimation of $g_{s}, E$ and stomatal density is genotype-dependent [12].

Table 5. Spectral characteristics of LED and HPS fixtures. For blue, green and red, spectral composition (\%) was calculated relative to the PPF range $(400-800 \mathrm{~nm})$ and rounded to an accuracy of $5 \%$.

\begin{tabular}{ccc}
\hline \multirow{2}{*}{ Light Quality Parameters } & \multicolumn{2}{c}{ Supplemental Light } \\
\cline { 2 - 3 } & LED & HPS \\
\hline$\%$ Blue $(400-500 \mathrm{~nm})$ & 5 & 5 \\
$\%$ Green-Yellow $(501-600 \mathrm{~nm})$ & 0 & 50 \\
$\%$ Red $(601-700 \mathrm{~nm})$ & 95 & 40 \\
\% Far-Red (701-800 nm) & 0 & 5 \\
(Green-Yellow):Blue & 0 & 10 \\
Red:Far Red & NA & 965 \\
\hline
\end{tabular}

\subsection{The Effects of Supplemental Light Spectral Quality on Plant Physiology}

Experiments 1, 2 and 3 were conducted during the fall-winter period, when the natural light photoperiod was, respectively, 9,7 and $9 \mathrm{~h}$ per day. This means that plants received only SL, respectively, for 7, 9 and $7 \mathrm{~h}$ per day, while during experiment 4 (conducted during winter-spring period), we had $3 \mathrm{~h}$ per day with only SL as the light source (Figure S2). Therefore, a greenhouse is not the best place to study the effect of SL spectral quality on the crop, because there is sunlight influence. Anyway, during this research activity, the young tomato plants received a great part of the radiation from SL fixtures (Figure S2), and in particular for the first three experiments, SL was the sole lighting source for a period between 7 and $9 \mathrm{~h}$ per day before sunrise. As the plants were grown mainly with SL radiation rather than solar light radiation, we hypothesized that we could find different physiological behaviours in response to different SL spectral qualities. In fact, HPS has a lower fraction of red (600-700 nm) compared to the LED light used in our experiments (Table 5). Furthermore, HPS light contains a substantial fraction of G-Y (500-600 nm), while LED did not (Table 5). The addition of $\mathrm{G}$ light to a R/B background has previously been shown to reverse $B$ light-induced stomatal opening $[20,21]$, and this has often been associated with a decrease in $g_{s}$ and $E[13,35,36]$. While IR wavelength and the thermal energy dissipation of HPS lamps contributed to increase leaf temperature compared with LED, the lower B:G ratio in HPS could be a signal for the plants to preserve their water status, thereby reducing $g_{s}$ and $E$ [22]. According to previous studies [13,22,35,37], we found that the plants grown under the lowest B:G SL ratio (HPS) showed the lowest stomatal density (Table 2). $g_{s}$ was 
higher under LED than HPS (Figure 1), except for 'LA1578', which showed a higher $g_{s}$ under HPS. For $E$, the same trend as for $g_{s}$ was observed (Table S2). Moreover, not only water vapour exchange but also photosynthetic capacity could be influenced by different SL spectra. In fact, specific regions in the shortwave spectrum can have strong effects on leaf light acclimation and, consequently, photosynthetic capacity [38-41]. In our study, global values of two parameters expressing photosynthetic capacity, maximum carboxylation rate $\left(\mathrm{V}_{\mathrm{c}, \max }\right)$ and electron transport rate at $1500 \mu \mathrm{mol} \mathrm{m}^{-2} \mathrm{~s}^{-1}$ PPFD $\left(J_{1500}\right)$ were significantly higher under LED (experiments 1 and 3, not in experiment 4; Figure 2). Although leaves under LED experienced slightly reduced temperatures compared to HPS (Table 3), they may have increased their photosynthetic machinery to correct for differences in enzyme turnover, which is strongly temperature-controlled [42,43]. The fact that the largest differences between HPS and LED in both leaf temperature (Table 3 ) and photosynthetic capacity (Figure 2) were observed in experiment 1 and experiment 2 underlines this hypothesis, as in these experiments the ratio between SL and solar light was highest. Additionally, given that HPS lamps had a larger output in both the G-Y and the FR region, it is tempting to speculate that the combination of these two colours led to shade acclimation (as discussed in Smith et al. [22]), which among other things would result in reduced photosynthetic capacity in these leaves. Between genotypes, $\mathrm{V}_{\mathrm{c}, \max }$ differed more strongly than $\mathrm{J}_{1500}$ and TPU; this suggests that Rubisco concentrations are more strongly affected by genotypic differences than either electron transport or triose phosphate utilization capacity.

\subsection{Plant Water Stress Indices for Phenotyping of Transpiration}

Stomatal conductance is often considered an important trait for future yield improvements, as it is positively related to photosynthesis [16]. Thermography was assessed as a technique to determine differences between genotypes in stomatal conductance and transpiration rate from CWSI and $\mathrm{I}_{\mathrm{G}}$. We measured $g_{s}$ with a porometer and a LI6400. Based on the studies of Jones [44] and Idso [45], $g_{s}$ can be derived from $\mathrm{I}_{\mathrm{G}}$ and CWSI non-invasively and potentially as high-throughput scalable measurements. CWSI can vary between 0 (no transpiration/ bad water status) and 1 (maximal transpiration/good water status). Young tomato plants grown under supplemental LED compared to HPS showed better water status (higher CWSI values; Table 4) and therefore a higher transpiration capacity. Positive correlations between $\mathrm{I}_{\mathrm{G}}, \mathrm{CWSI}, g_{s}$ and E, as described in previous studies $[27,45,46]$, were confirmed. Our hypothesis was that the climatic conditions under LED and the spectral quality of the LED modules positively influenced stomata behaviour and the gas exchange system, improving the overall plant water status compared with HPS treatment. Moreover, 'Rutgers' showed a value of CWSI that was not significantly different between HPS and LED, while for 'LA1578', CWSI was lower under HPS than under LED (Figure 3). Therefore, preliminary measurements for each genotype will be necessary (to find the leaf absorption coefficient [47]) to use this technique to predict $g_{s}$. With thermography, it is possible to estimate plant water status and to predict $g_{s}$ using rapid and noninvasive measurements-this may open up possibilities, especially in the field of plant genetic improvement.

\section{Materials and Methods}

\subsection{Plant Material and Growth Conditions}

Seven tomato genotypes (Solanum lycopersicum L.: 'Moneymaker', 'Momotaro', 'Rutgers', 'Ailsa Craig', 'Kentuky Beefsteak' and 'Nunhems-FM001'; and Solanum pimpinellifolium L.: 'LA1578') were grown in four greenhouse experiments during the 2018-2019 winter/spring season: experiment 1 (Oct.-Nov.), experiment 2 (Dec.-Jan.), experiment 3 (Jan.-Feb.) and experiment 4 (Mar.-Apr.). Seeds were sown on stonewool plugs (Grodan, Roermond, The Netherlands) and germinated in the glasshouse facilities (Unifarm) of Wageningen University, the Netherlands $\left(53^{\circ} \mathrm{N}, 5.5^{\circ} \mathrm{E}\right)$, under supplemental HPS or LED light. Seven days after sowing, seedlings in plugs were transferred to $10 \times 10 \times 6 \mathrm{~cm}$ stonewool blocks (Grodan) and placed on ebb and flow benches, for four weeks in experi- 
ment 1 and for ca. three weeks in the other experiments (three plants per genotype were placed on each bench), under either HPS and LED red/blue supplemental lighting. The experimental layout consisted of three benches per supplemental lighting condition, with three plants of each genotype on each ebb and flow bench. Nine plants for each genotype were grown under HPS and nine plants under LED (Figure 5). HPS-lighting (Master green power, cgt 400W, Signify, Eindhoven, The Netherlands) or DR/LB LED-lighting (Green Power LED top lighting module, 190W, Signify) were applied at about $200 \mu \mathrm{mol} \mathrm{m}{ }^{-2} \mathrm{~s}^{-1}$ photosynthetic photon flux density (PPFD) at plant level, and lamps were switched on $16 \mathrm{~h}$ before sunset and switched off at sunset. HPS light contains a substantial fraction of yellow (Y) to G (501-600 nm), while LED did not (Table 5). The 501 to $600 \mathrm{~nm}$ range of HPS light two peaks in the G-Y light segment at $550 \mathrm{~nm}$ and at $580 \mathrm{~nm}$ [48]. For LED fixtures, the emission peaks were at ca. 650 and $450 \mathrm{~nm}$, having peaks only in $\mathrm{B}$ and $\mathrm{R}$ regions with very little output in the FR region (Table 5).
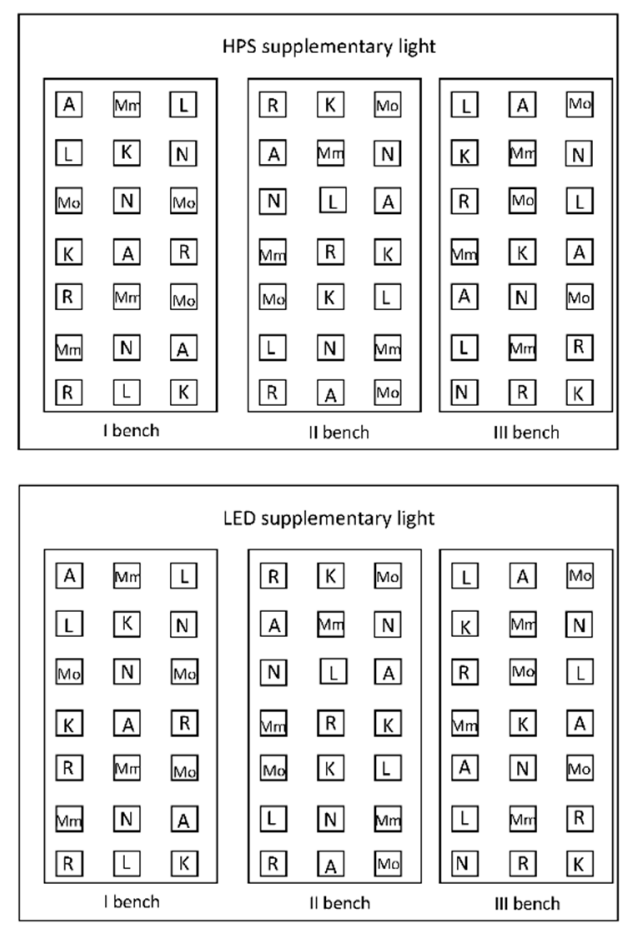

Figure 5. Experimental layout. Tomato plants (7 genotypes) grown in two adjacent greenhouse compartments of each $60 \mathrm{~m}^{2}$ with different supplementary light technologies (HPS vs. LED). A-Ailsa Craig; K-Kentucky Beefsteak; L-LA1578; Mm-Moneymaker; Mo-Momotaro; N-Nunhems-FM001; R-Rutgers. The plants were interspaced by other tomato plants (that were not evaluated in this study) growing ca. $8 \mathrm{~cm}$ apart.

A standard nutrient solution $\left(\mathrm{pH}=\right.$ ca. $5.5, \mathrm{EC}=2.0 \mathrm{dS} \mathrm{m}^{-1}, \mathrm{NH}_{4}=1.2, \mathrm{~K}=7.2$, $\mathrm{Ca}=4.0, \mathrm{Mg}=1.82, \mathrm{NO}_{3}=12.4, \mathrm{SO}_{4}=3.32, \mathrm{P}=1.0 \mathrm{mmol} \mathrm{L}^{-1}$ and $\mathrm{Fe}=35.0, \mathrm{Mn}=8.0$, $\mathrm{Zn}=5.0, \mathrm{~B}=20.0, \mathrm{Cu}=0.5, \mathrm{Mo}=0.5 \mu \mathrm{mol} \mathrm{L}{ }^{-1}$ ) was used for fertigation. Plants were watered daily, without differences between the compartments. Average air temperature during the day from the first to the fourth experiment was, respectively: 22.8, 22.9, 23.2 and $24.8^{\circ} \mathrm{C}$; air temperature during the night was, respectively: $19.2,19.2,19.4$ and $19.5^{\circ} \mathrm{C}$ (Figure S3). Relative air humidity (RH) was set at $70 \%$. When global radiation outside the greenhouse exceeded $200 \mathrm{~W} \mathrm{~m}^{-2}$, a shading screen (42\% light reduction, Harmony 4215 O FR) was closed to prevent excessive sunlight from entering the greenhouse. To prevent light pollution from adjacent compartments, all side walls of the greenhouse compartments were closed off, using white horticultural plastic foil. The greenhouse climate was recorded by a horticultural sensor box (Hoogendoorn-Economic; Hoogendoorn, Vlaardingen, the Netherlands). During each experiment, the environmental conditions between the two 
experimental compartments, apart from SL treatment spectra, were kept identical. For experiment 1 , the daily light integral (DLI) received by the plants (combination of natural light and SL) was on average $20 \mathrm{~mol} \mathrm{~m}^{-2} \mathrm{~d}^{-1}$ and $75 \%$ of the total light was SL (Figure S2); the average DLI in experiment 2 was similar to experiment $1\left(18.8 \mathrm{~mol} \mathrm{~m}^{-2} \mathrm{~d}^{-1}\right.$; Figure S2); however, the fraction of SL in total light was higher (82\%; Figure S2); for experiment 3, the average DLI was $21.3 \mathrm{~mol} \mathrm{~m}^{-2} \mathrm{~d}^{-1}$, and $73 \%$ of it was supplemental light (Figure S2); finally, during experiment 4 , the average DLI was $29 \mathrm{~mol} \mathrm{~m}^{-2} \mathrm{~d}^{-1}$, and therefore was much higher than in experiments 1-3, while the fraction SL in total light was only $61 \%$ (Figure S2).

\subsection{Daily Light Integral (DLI) and Light Quality}

To determine the greenhouse transmissivity, PPFD at plant level was measured on a cloudy day with a quantum sensor (LI-191SA, LI-COR Biosciences, Lincoln, NE, USA) while concomitantly measuring global radiation $\left(\mathrm{W} \mathrm{m}^{-2}\right)$ outside the greenhouse using a solarimeter (Kipp en Zonen, Delft, The Netherlands). The fraction of photosynthetic photon flux (PPF; $400-700 \mathrm{~nm}$ ) in the total global radiation was assumed to be $47 \%$ (Britton and Dodd (1976)), and the conversion factor from energy flux to quantum flux in the PPF region of sunlight $4.57 \mu \mathrm{mol} \mathrm{J}^{-1}$ [49]. Greenhouse transmissivity (\%) was calculated as:

Greenhouse transmissivity $(\%)=$ PPFD at plant level $/($ Global radiation $\times 0.47 \times 4.57) \times 100$

Where PPFD: photosynthetic photon flux density $(\mu \mathrm{mol} \cdot \mathrm{m}-2 \cdot \mathrm{s}-1)$

Global radiation outside the greenhouse was measured every five minutes. When the shading screen was closed, greenhouse transmissivity decreased by $\sim 42 \%$. To calculate PPFD supplied from supplemental light (SL), the number of hours during which SL was switched on was multiplied by its intensity. Light quality of a HPS and LED lamp was measured at $1 \mathrm{~m}$ distance with a field spectroradiometer (SS-110, Apogee instruments, Logan, UT, United States). Light intensity at plant level was measured with a quantum sensor (LI-COR, LI-190R Quantum Sensor).

\subsection{Stomatal Conductance $\left(g_{s}\right)$ and Transpiration Rate (E)}

All physiological measurements took place in weeks 3-4 after the start of treatments. The outermost three leaflets of the most fully expanded leaf were used (third or fourth leaf, depending on cultivar, counting from the base) per plant and three plants per genotype were measured. In all experiments, $g_{s}$ was measured with a porometer (Decagon Devices Inc., Pullman, WA, USA), which was calibrated daily with fresh desiccant to ensure accurate measurements. To confirm the results obtained with porometer and to measure $g_{s}$ and $\mathrm{E}$ at the same time, during experiments 3 and 4, the LI-6400 photosynthesis system (Li-Cor) was used. Using a transparent cuvette (enclosed leaf area: $6 \mathrm{~cm}^{2}$ ), leaflets were enclosed at $400 \pm 1.3 \mu$ bar $\mathrm{CO}_{2}, 22.4 \pm 0.2{ }^{\circ} \mathrm{C}$ cuvette temperature, $70 \pm 1 \% \mathrm{RH}$ and a flow rate of $500 \mu \mathrm{mol} \mathrm{s}^{-1}$. After they had reached stability, $g_{s}$ and $E$ were logged 10 times at $30 \mathrm{~s}$ intervals (to be sure we logged a representative value); these values were later averaged over the 3 biological replicates to increase accuracy. To minimize the effects of diurnal changes in temperature and light intensity, measurements of $g_{s}$ and $E$ were performed alternatively between the HPS and LED compartment (three plants per compartment were alternatively measured).

\subsection{Photosynthetic $\mathrm{CO}_{2}$ Response Curves}

The response of net photosynthesis rate $\left(\mathrm{A} ; \mu \mathrm{mol} \mathrm{m}^{-2} \mathrm{~s}^{-1}\right)$ to leaf internal $\mathrm{CO}_{2}$ partial pressure $\left(C_{i}, \mu b a r\right)$ was determined during experiment 1,3 and 4 . The LI-6400, equipped with the $6400-40$ fluorescence cuvette $(90 \% \mathrm{R} / 10 \%$ B spectrum at peak intensities of 635 and $465 \mathrm{~nm}$, respectively; enclosed leaf area: $2 \mathrm{~cm}^{2}$ ), was used. The measurements were done on one leaf per plant for three plants per genotype for each bench. Leaves were enclosed in the cuvette at $1500 \mu \mathrm{mol} \mathrm{m} \mathrm{m}^{-2} \mathrm{~s}^{-1} \mathrm{PPFD}, 101.5 \pm 0.05 \mathrm{kPa}$ atmospheric pressure, $23 \pm 0.2{ }^{\circ} \mathrm{C}$ cuvette temperature, $70 \pm 5 \% \mathrm{RH}$, a flow rate of $400 \mu \mathrm{mol}$ air s${ }^{-1}$ and $400 \pm 2 \mu \mathrm{bar} \mathrm{CO}_{2}$ 
partial pressure. After waiting for A to stabilize ( $\sim 15 \mathrm{~min}), \mathrm{CO}_{2}$ partial pressure was changed in steps to 300,100, 50,400,400,600, 850, 1100 and $1400 \mu$ bar, while all other environmental variables were kept constant. At each $\mathrm{CO}_{2}$ step (2-3 min duration), after A was stabilized, values of $\mathrm{CO}_{2}$ and $\mathrm{H}_{2} \mathrm{O}$ measured by the infrared gas sensor of the sample cell were calibrated against those of the reference cell ("matching"), and A was logged. A and $\mathrm{C}_{\mathrm{i}}$ values were corrected for leaks of $\mathrm{CO}_{2}$ into or out of the cuvette, according to Long and Bernacchi [50]. From $\mathrm{CO}_{2}$ response curves, $\mathrm{V}_{\mathrm{c} \text {,max }}$ (maximum carboxylation rate), $\mathrm{J}_{1500}$ (electron transport rate at $1500 \mu \mathrm{mol} \mathrm{m}^{-2} \mathrm{~s}^{-1}$ ) and TPU (maximum triose phosphate utilization rate) were determined according to Sharkey [51], including a leaf temperature correction to $25^{\circ} \mathrm{C}$. For fitting of $\mathrm{CO}_{2}$ response curves, mesophyll conductance was assumed to be $0.189 \mathrm{~mol} \mathrm{~m}^{-2} \mathrm{~s}^{-1}$, as determined for young tomato leaves [52], while data from A vs. PPFD in the range 0-300 $\mu \mathrm{mol} \mathrm{m}{ }^{-2} \mathrm{~s}^{-1}$ PPFD (determined during experiment 1 ) were used to calculate day respiration $\left(R_{d}\right)$. A negative-exponential function was fitted to A/PPFD, and the resulting intercept value was used as $R_{d}$. Since $\mathrm{R}_{\mathrm{d}}$ was not significantly different between treatments $(p=0.14)$ or genotypes $(p=0.23)$, a global value of $\mathrm{R}_{\mathrm{d}}=2.1 \pm 0.1 \mu \mathrm{mol} \mathrm{m} \mathrm{m}^{-2}$ was used for fitting $\mathrm{CO}_{2}$ response curves.

\subsection{Stomatal Density}

In experiments 3 and 4, on 20 DAT, one stomatal imprint per biological replicate (with three biological replicates per genotype) was taken on the leaf abaxial side using the silicon rubber impression technique [53]. Stomatal density was measured on images (800-fold magnification) of the imprints (Figure S1) using a microscope (Leica, Aristoplan, Wetzlar, Germany) connected to a digital camera (DXM-1200, Nikon, Tokyo, Japan). Per imprint, stomata were counted on a randomly selected area of $0.25 \mathrm{~mm}^{2}$. Image processing and count of stomata was done using ImageJ (University of Texas Health Science Centre at San Antonio, TX, USA).

\subsection{Leaf Temperature}

Leaf temperature was measured with (i) an infrared non-contact thermometer (Raynger ST, Raytek, Santa Cruz, CA, USA) in experiment 3, and (ii) using a thermal camera (FLIR A655sc w $/ 25^{\circ}$ lens, $640 \times 480$, FLIR Systems, Ltd. Burlington, ON, Canada) in all four experiments. Measurements were conducted in weeks 3-4 after transplanting. For (i) and (ii), the temperature of the outermost three leaflets of the most fully expanded leaf, which was approximately perpendicular to the lamps, was measured. Measurements with the infrared thermometer took place one hour before sunrise, while lamps were switched on, to avoid the influence of solar radiation on leaf temperature. To correct for the different temperatures at plant level in the HPS and LED compartments, the temperature of a reference leaf (green printer paper Gemini green, $90 \mathrm{~g} \mathrm{~m}^{-2}$, Astrobrights by Wausau papers, Mosinee, WI, USA) was also measured.

Using the thermal camera, leaf temperature readings from thermal images were taken over a circle with an area of $6 \mathrm{~cm}^{2}$. Per measurement, 30 images were captured for $15 \mathrm{~min}$ (1 image was captured every $30 \mathrm{~s}$ ) and an average temperature was calculated. Leaf heat emissivity was assumed to be 0.95 [46]. To minimize the effects of diurnal changes in air temperature on leaf temperature, images were recorded alternatively in HPS and LED compartments (three plants from different genotype per compartment were alternatively measured). Reference surfaces were used to establish a temperature range to simulate leaves at 100\% (wet reference) and 0\% (dry reference) transpiration. Reference surfaces were used to normalize the data obtained per measurement. Green printer paper (Gemini green) was used as dry reference and white filter paper grade 597 (VWR International LLC, Radnor, PA, USA), which was sprayed continuously with distilled water, was used as a wet reference. These materials were cut into shapes resembling tomato leaflets and attached to sticks, so the papers were hanging freely in the air. 


\subsection{Plant Water Stress Indices}

From the thermal images, the thermal index $\left(\mathrm{I}_{\mathrm{G}}\right)[44]$ was calculated as:

$$
\mathrm{I}_{\mathrm{G}}=\left(\mathrm{T}_{\text {dry }}-\mathrm{T}_{\text {leaf }}\right) /\left(\mathrm{T}_{\text {leaf }}-\mathrm{T}_{\text {wet }}\right) ;
$$

with $T_{\text {dry }}$ as dry reference, $T_{\text {leaf }}$ as leaf and $T_{\text {wet }}$ as wet reference temperature, respectively. The value of $\mathrm{I}_{\mathrm{G}}$ can vary from 0 (no transpiration) to $\infty$ (maximal transpiration); and the crop water stress index (CWSI) [45] was calculated as:

$$
\text { CWSI }=\left(\mathrm{T}_{\text {dry }}-\mathrm{T}_{\text {leaf }}\right) /\left(\mathrm{T}_{\text {dry }}-\mathrm{T}_{\mathrm{wet}}\right)
$$

CWSI can vary from 0 (no transpiration) to 1 (maximal transpiration).

\subsection{Statistical Analysis}

Each experiment was considered as an independent activity. Three replicate plants per genotype were evaluated per experiment. Data were first tested for homogeneity (Levene's test) and for normal distribution of variances (Shapiro-Wilk test). The experimental factors were fixed in a two-way analysis of variance (ANOVA). To determine differences between means, a Tukey test was used. Correlations were tested using Pearson's correlation coefficient. Analyses were performed using R (version 3.4.3, R Foundation for Statistical Computing, Vienna, Austria). Packages used for the analysis were: agricolae [54], multcompView [55], car [56] and ggpubr [57].

\section{Conclusions}

Leaves of young tomato plants under LED showed higher gas exchange and photosynthetic capacity compared to HPS; this may be related to the increased leaf temperature under HPS, causing subtle but detectable differences in environmental acclimation. The fact that leaves were warmer under HPS lamps could be a result of the higher heat radiation (NIR light) relative to LED lamps. Moreover, the presence of green light in HPS lamps may have led to stomatal closure and/or reduced stomatal density, in turn reducing transpiration and increasing leaf temperature. Genotypic differences were observed for $E$, $g_{s}$, stomatal number and photosynthetic capacity. However, no genotypic differences were identified for leaf temperature. At higher ratios between natural light and SL (experiment 4), differences between HPS and LED were smaller. Finally, our results demonstrate that thermography is a potentially rapid and noninvasive technique to study plant water status and predict $g_{s}$. However, further studies on, e.g., validation under a wide range of different conditions will be necessary to improve the accuracy of this prediction.

Supplementary Materials: The following are available online at https:/ / www.mdpi.com/article/10 .3390/plants10040810/s1, Figure S1: Stomatal imprint of cv. 'Rutgers' grown under LEDs supplemental light; Figure S2: Daily light integral from natural light $\left(\mathrm{DLI}_{\mathrm{nl}}\right)$, from supplemental light $\left(\mathrm{DLI}_{\mathrm{sl}}\right)$ and the sum of DLI from supplemental light plus natural light $\left(\mathrm{DLI}_{\mathrm{n}+\mathrm{sl}}\right)$; Figure S3: Air temperature $\left({ }^{\circ} \mathrm{C}\right)$ in greenhouse compartments; Table S1: Stomatal conductance $\left(g_{s}\right)$ measured with the porometer per genotype and experiment.; Table S2: Average stomatal conductance and transpiration rate (measured with LI-6400 XT) in seven tomato genotypes grown under HPS and LED supplemental light; Table S3: Thermal Index $(\operatorname{Ig})$ per treatment $(n=21)$ and genotype $(n=3)$. Table S3: Thermal Index $\left(\mathrm{I}_{\mathrm{g}}\right)$ per treatment $(n=21)$ and genotype $(n=3)$.

Author Contributions: Conceptualization, O.D.P., A.E.P., E.K., E.H.; methodology, O.D.P., A.E.P., E.K., E.H.; formal analysis, O.D.P., A.E.P.; data curation, O.D.P., A.E.P., E.K.; writing-original draft preparation, O.D.P.; writing-review and editing, O.D.P., A.E.P., E.K., E.H.; supervision, A.E.P., E.K., E.H.; funding acquisition, E.H. All authors have read and agreed to the published version of the manuscript.

Funding: This research was funded by LEDitBE50\% project from NWO and by the programme: ESF-ERDF Research and Innovation PON 2014-2020, Action I.1 “Innovative PhDs with industrial characterization". 
Data Availability Statement: The raw data supporting the conclusions of this article will be made available by the authors, without undue reservation.

Acknowledgments: We thank Hanneke van der Schoot for her valuable support in setting up the experiment. We thank Nunhems Nederlands B.V. (BASF Vegetable Seeds), Rijk Zwaan Nederland B.V., Bejo Zaden B.V. and Signify B.V. for funding in the framework of the LEDitBE50\% project from NWO. In addition, we thank Signify B.V. for providing the LED lamps and making the light plan. Cees Schuit, Joost Baars, Frank Millenaar, Corine de Groot, Céline C. S. Nicole, Maarten Verlaan, Maaike Wubs for discussions. For managing the greenhouse we thank Maarten Peters, André Maassen, Sean Geurts, Geurt Versteeg, Ad Hermsen and Rohan van Genderen. For further technical advice and help we thank Maarten Wassenaar, Joke Oosterkamp, Erik Schuiling and Tijmen Kerstens.

Conflicts of Interest: The authors declare no conflict of interest.

\begin{abstract}
Abbreviations

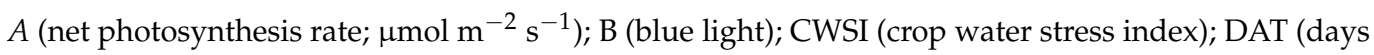
after start of treatments); DLI (daily light integral; $\mathrm{mol} \mathrm{m}^{-2} \mathrm{~d}^{-1}$ ); $E$ (transpiration rate; $\mathrm{mol} \mathrm{H}_{2} \mathrm{O} \mathrm{m}^{-2}$ $\mathrm{s}^{-1}$ ); FR (far-red light); $\mathrm{G}$ (green light); $\mathrm{G}_{\mathrm{n}}$ (genotype); $g_{s}$ (stomatal conductance; $\mathrm{mol}_{2} \mathrm{O} \mathrm{m}^{-2} \mathrm{~s}^{-1}$ ); HPS (high pressure sodium); $\mathrm{I}_{\mathrm{G}}$ (thermal index); IR (infrared); $\mathrm{J}_{1500}$ (maximum electron transport rate at $1500 \mu \mathrm{mol} \mathrm{m}{ }^{-2} \mathrm{~s}^{-1} ; \mu \mathrm{mol} \mathrm{m} \mathrm{m}^{-2} \mathrm{~s}^{-1}$ ); LED (light emitting diodes); PPF (photosynthetic photon flux; $\mu \mathrm{mol} \mathrm{m} \mathrm{m}^{-2}$ ); PPFD (photosynthetic photon flux density; $\mu \mathrm{mol} \mathrm{m}{ }^{-2} \mathrm{~s}^{-1}$ ); $\mathrm{R}$ (red light); $\mathrm{R}_{\mathrm{d}}$ (day respiration; $\mu \mathrm{mol} \mathrm{m} \mathrm{m}^{-2} \mathrm{~s}^{-1}$ ); $\mathrm{RH}$ (relative humidity; \%); SL (supplemental light); $\mathrm{T}_{\text {dry }}$ (dry reference temperature; ${ }^{\circ} \mathrm{C}$ ); $\mathrm{T}_{\text {leaf }}$ (leaf temperature; ${ }^{\circ} \mathrm{C}$ ); TPU (maximum triose phosphate utilization rate; $\mu \mathrm{mol}$ $\mathrm{m}^{-2} \mathrm{~s}^{-1}$ ); $\mathrm{T}_{\text {wet }}$ (wet reference temperature; ${ }^{\circ} \mathrm{C}$ ); $\mathrm{V}_{\mathrm{c}, \max }$ (maximum carboxylation rate; $\mu \mathrm{mol} \mathrm{m}^{-2}$ $\left.\mathrm{s}^{-1}\right)$; $\mathrm{Y}$ (yellow light).
\end{abstract}

\title{
References
}

1. Gómez, C.; Mitchell, C.A. Supplemental lighting for greenhouse-grown tomatoes: Intracanopy LED towers vs overhead HPS lamps. Acta Hortic. 2014, 1037, 855-862. [CrossRef]

2. Wei, H.; Zhao, J.; Hu, J.; Jeong, B.R. Effect of supplementary light intensity on quality of grafted tomato seedlings and expression of two photosynthetic genes and proteins. Agronomy 2019, 9, 339. [CrossRef]

3. Toida, H.; Ohyama, K.; Omura, Y.; Kozai, T. Enhancement of growth and development of tomato seedlings by extending the light period each day. HortScience 2005, 40, 370-373. [CrossRef]

4. Kim, H.M.; Hwang, S.J. The growth and development of 'mini chal' tomato plug seedlings grown under various wavelengths using light emitting diodes. Agronomy 2019, 9, 157. [CrossRef]

5. Kim, H.; Lin, M.; Mitchell, C.A. Light spectral and thermal properties govern biomass allocation in tomato through morphological and physiological changes. Environ. Exp. Bot. 2019, 157, 228-240. [CrossRef]

6. Särkkä, L.E.; Jokinen, K.; Ottosen, C.O.; Kaukoranta, T. Effects of HPS and LED lighting on cucumber leaf photosynthesis, light quality penetration and temperature in the canopy, plant morphology and yield. Agric. Food Sci. 2017, 26, 101-109. [CrossRef]

7. Morrow, R.C. LED lighting in horticulture. HortScience 2008, 43, 1947-1950. [CrossRef]

8. Gilewski, M. The state of art in the horticulture lighting. Photonics Lett. Pol. 2020, 12, 100-102. [CrossRef]

9. Nelson, J.A.; Bugbee, B. Analysis of environmental effects on leaf temperature under sunlight, high pressure sodium and light emitting diodes. PLoS ONE 2015, 10, e0138930. [CrossRef]

10. Leong, T.; Anderson, J.A.N.M. Changes in composition and function of thylakoid membranes as a result of photosynthetic adaptation of chloroplast from pea plants grown under different light conditions. Biochim. Biophys. Acta. 1983, 723, 391-399. [CrossRef]

11. Rascher, U.; Nedbal, L. Dynamics of photosynthesis in fluctuating light. Curr. Opin. Plant Biol. 2006, 9, 671-678. [CrossRef]

12. Gratani, L. Plant phenotypic plasticity in response to environmental factors. Adv. Bot. 2014, 2014, 1-17. [CrossRef]

13. Liu, X.Y.; Chang, T.T.; Guo, S.R.; Xu, Z.G.; Li, J. Effect of different light quality of LED on growth and photosynthetic character in cherry tomato seedling. Acta Hortic. 2011, 907, 325-330. [CrossRef]

14. Wang, J.; Lu, W.; Tong, Y.; Yang, Q. Leaf morphology, photosynthetic performance, chlorophyll fluorescence, stomatal development of lettuce (Lactuca sativa L.) exposed to different ratios of red light to blue light. Front. Plant Sci. 2016, 7, 1-10. [CrossRef] [PubMed]

15. Giuliani, R.; Koteyeva, N.; Voznesenskaya, E.; Evans, M.A.; Cousins, A.B.; Edwards, G.E. Coordination of leaf photosynthesis, transpiration, and structural traits in rice and wild relatives (Genus Oryza). Plant Physiol. 2013, 162, 1632-1651. [CrossRef]

16. Fischer, R.A.; Rebetzke, G.J. Indirect selection for potential yield in early-generation, spaced plantings of wheat and other small-grain cereals: A review. Crop Pasture Sci. 2018, 69, 439-459. [CrossRef]

17. Lanoue, J.; Leonardos, E.D.; Khosla, S.; Hao, X.; Grodzinski, B. Effect of elevated $\mathrm{CO}_{2}$ and spectral quality on whole plant gas exchange patterns in tomatoes. PLOS ONE 2018, 13, e0205861. [CrossRef] [PubMed] 
18. Wei, H.; Xiaoxiao, W.; Min, P.; Xiaoying, L.; Lijun, G.; Zhigang, X. Effect different spectral LED on photosynthesis and distribution of photosynthate of cherry tomato seedlings. In Proceedings of the 14th China International Forum on Solid State Lighting: International Forum on Wide Bandgap Semiconductors China (SSLChina: IFWS), Beijing, China, 1-3 November 2017; pp. 78-84.

19. Eisinger, W.R.; Bogomolni, R.A.; Taiz, L. Interactions between a blue-green reversible photoreceptor and a separate UV-B receptor in stomatal guard cells. Am. J. Bot. 2003, 90, 1560-1566. [CrossRef]

20. Frechilla, S.; Talbott, L.D.; Bogomolni, R.A.; Zeiger, E. Reversal of blue light-stimulated stomatal opening by green light. Plant Cell Physiol. 2000, 41, 171-176. [CrossRef]

21. Talbott, L.D.; Nikolova, G.; Ortiz, A.; Shmayevich, I.; Zeiger, E. Green light reversal of blue-light-stimulated stomatal opening is found in a diversity of plant species. Am. J. Bot. 2002, 89, 366-368. [CrossRef]

22. Smith, H.L.; Mcausland, L.; Murchie, E.H. Don't ignore the green light: Exploring diverse roles in plant processes. J. Exp. Bot. 2017, 68, 2099-2110. [CrossRef]

23. Li, S.; Hamani, A.K.M.; Si, Z.; Liang, Y.; Gao, Y.; Duan, A. Leaf gas exchange of tomato depends on abscisic acid and jasmonic acid in response to neighboring plants under different soil nitrogen regimes. Plants 2020, 9, 1674. [CrossRef] [PubMed]

24. Reynolds, D.; Baret, F.; Welcker, C.; Bostrom, A.; Ball, J.; Cellini, F.; Lorence, A.; Chawade, A.; Khafif, M.; Noshita, K.; et al. What is cost-efficient phenotyping? Optimizing costs for different scenarios. Plant Sci. 2019, 282, 14-22. [CrossRef]

25. Vialet-Chabrand, S.; Lawson, T. Dynamic leaf energy balance: Deriving stomatal conductance from thermal imaging in a dynamic environment. J. Exp. Bot. 2019, 70, 2839-2855. [CrossRef]

26. Vialet-Chabrand, S.; Lawson, T. Thermography methods to assess stomatal behaviour in a dynamic environment. J. Exp. Bot. 2020, 71, 2329-2338. [CrossRef]

27. Jones, H.G. Use of infrared thermography for monitoring stomatal closure in the field: Application to grapevine. J. Exp. Bot. 2002, 53, 2249-2260. [CrossRef]

28. Mott, K.A.; Peak, D. Stomatal responses to humidity and temperature in darkness. Plant Cell Environ. 2010, 33, 1084-1090. [CrossRef]

29. von Caemmerer, S.; Evans, J.R. Temperature responses of mesophyll conductance differ greatly between species. Plant Cell Environ. 2015, 38, 629-637. [CrossRef] [PubMed]

30. Lahr, E.C.; Schade, G.W.; Crossett, C.C.; Watson, M.R. Photosynthesis and isoprene emission from trees along an urban-rural gradient in Texas. Glob. Chang. Biol. 2015, 21, 4221-4236. [CrossRef] [PubMed]

31. Bañon, S.; Fernandez, J.A.; Franco, J.A.; Torrecillas, A. Effects of water stress and night temperature preconditioning on water relations and morphological and anatomical changes of Lotus creticus plants. Sci. Hortic. 2004, 101, 333-342. [CrossRef]

32. Farquhar, G.D.; Sharkey, T.D. Stomatal conductance and photosynthesis. Annu. Rev. Plant Physiol. 1982, 33, 317-345. [CrossRef]

33. Xu, Z.; Zhou, G. Responses of leaf stomatal density to water status and its relationship with photosynthesis in a grass. J. Exp. Bot. 2008, 59, 3317-3325. [CrossRef] [PubMed]

34. Sobejano-Paz, V.; Mikkelsen, T.N.; Baum, A.; Mo, X.; Liu, S.; Köppl, C.J.; Johnson, M.S.; Gulyas, L.; García, M. Hyperspectral and thermal sensing of stomatal conductance, transpiration, and photosynthesis for soybean and maize under drought. Remote Sens 2020, 12, 3182. [CrossRef]

35. Kim, H.H.; Goins, G.D.; Wheeler, R.M.; Sager, J.C. Stomatal conductance of lettuce grown under or exposed to different light qualities. Ann. Bot. 2004, 94, 691-697. [CrossRef]

36. Muneer, S.; Kim, E.J.; Park, J.S.; Lee, J.H. Influence of green, red and blue light emitting diodes on multiprotein complex proteins and photosynthetic activity under different light intensities in lettuce leaves (Lactuca sativa L.). Int. J. Mol. Sci. 2014, 15, 4657-4670. [CrossRef] [PubMed]

37. XiaoYing, L.; ShiRong, G.; ZhiGang, X.; XueLei, J.; Tezuka, T. Regulation of chloroplast ultrastructure, cross-section anatomy of leaves, and morphology of stomata of cherry tomato by different light irradiations of light-emitting diodes. HortScience 2011, 46, 217-221. [CrossRef]

38. Hogewoning, S.W.; Trouwborst, G.; Maljaars, H.; Poorter, H.; van Ieperen, W.; Harbinson, J. Blue light dose-responses of leaf photosynthesis, morphology, and chemical composition of Cucumis sativus grown under different combinations of red and blue light. J. Exp. Bot. 2010, 61, 3107-3117. [CrossRef]

39. Trouwborst, G.; Hogewoning, S.W.; van Kooten, O.; Harbinson, J.; van Ieperen, W. Plasticity of photosynthesis after the 'red light syndrome' in cucumber. Environ. Exp. Bot. 2016, 121, 75-82. [CrossRef]

40. Ji, Y.; Ouzounis, T.; Courbier, S.; Kaiser, E.; Nguyen, P.T.; Schouten, H.J.; Visser, R.G.F.; Pierik, R.; Marcelis, L.F.M.; Heuvelink, E. Far-red radiation increases dry mass partitioning to fruits but reduces Botrytis cinerea resistance in tomato. Environ. Exp. Bot. 2019, 168, 103889. [CrossRef]

41. Kaiser, E.; Ouzounis, T.; Giday, H.; Schipper, R.; Heuvelink, E.; Marcelis, L.F.M. Adding blue to red supplemental light increases biomass and yield of greenhouse-grown tomatoes, but only to an optimum. Front. Plant Sci. 2019, 9, 2002. [CrossRef]

42. Yamori, W.; Noguchi, K.; Hikosaka, K.; Terashima, I. Phenotypic plasticity in photosynthetic temperature acclimation among crop species with different cold tolerances. Plant Physiol. 2010, 152, 388-399. [CrossRef]

43. Yamori, W.; Hikosaka, K.; Way, D.A. Temperature response of photosynthesis in C3, C4, and CAM plants: Temperature acclimation and temperature adaptation. Photosynth. Res. 2014, 119, 101-117. [CrossRef] [PubMed]

44. Jones, H.G. Use of thermography for quantitative studies of spatial and temporal variation of stomatal conductance over leaf surfaces. Plant Cell Environ. 1999, 22, 1043-1055. [CrossRef] 
45. Idso, S.B. Non-water-stressed baselines: A key to measuring and interpreting plant water stress. Agric. Meteorol. 1982, 27, 59-70. [CrossRef]

46. Jones, H.G. Application of thermal imaging and infrared sensing in plant physiology and ecophysiology. Adv. Bot. Res. 2004, 41, 107-163. [CrossRef]

47. Fourty, T.; Baret, F.; Jacquemoud, S.; Schmuck, G.; Verdebout, J. Leaf optical properties with explicit description of its biochemical composition: Direct and inverse problems. Remote Sens. Environ. 1996, 56, 104-117. [CrossRef]

48. Lanoue, J.; Leonardos, E.D.; Ma, X.; Grodzinski, B. The effect of spectral quality on daily patterns of gas exchange, biomass gain, and water-use-efficiency in tomatoes and Lisianthus: An assessment of whole plant measurements. Front. Plant Sci. 2017, 8, 1076. [CrossRef]

49. McCree, K.J. The action spectrum, absorptance and quantum yield of photosynthesis in crop plants. Agric. Meteorol. 1972, 9, 191-216. [CrossRef]

50. Long, S.P.; Bernacchi, C.J. Gas exchange measurements, what can they tell us about the underlying limitations to photosynthesis? Procedures and sources of error. J. Exp. Bot. 2003, 54, 2393-2401. [CrossRef]

51. Sharkey, T.D. What gas exchange data can tell us about photosynthesis. Plant Cell Environ. 2016, 39, 1161-1163. [CrossRef]

52. Berghuijs, H.N.C.; Yin, X.; Tri Ho, Q.; van der Putten, P.E.L.; Verboven, P.; Retta, M.A.; Nicolaï, B.M.; Struik, P.C. Modeling the relationship between $\mathrm{CO}_{2}$ assimilation and leaf anatomical properties in tomato leaves. Plant Sci. 2015, 238, 297-311. [CrossRef] [PubMed]

53. Smith, S.; Weyers, J.D.B.; Berry, W.G. Variation in stomatal characteristics over the lower surface of Commelina communis leaves. Plant Cell Environ. 1989, 12, 653-659. [CrossRef]

54. de Mendiburu, F. Agricolae; Universidad Nacional Agraria La Molina: Lima, Peru, 2020.

55. Graves, S.; Piepho, H.-P.; Selzer, L. Multcompview: Visualizations of Paired Comparisons. R Package Version 0.1-5. 2019. Available online: http:/ /CRAN.Rproject.org/package=multcompView (accessed on 21 January 2021).

56. Fox, J.; Weisberg, S. An R Companion to Applied Regression, 3rd ed.; Sage Publications: Thousand Oaks, CA, USA, 2014.

57. Kassambara, A. Ggpubr: "Ggplot2" Based Publication Ready Plots. R Package Version 0.2. 2018. Available online: https: / /CRAN.R-project.org/package=ggpubr (accessed on 21 January 2021). 